\title{
Identifying an appropriate approach to judge low carbon buildings
}

\author{
Isiadinso, C
}

http://hdl.handle.net/10026.1/9279

10.1108/02630801111182457

Structural Survey

Emerald

All content in PEARL is protected by copyright law. Author manuscripts are made available in accordance with publisher policies. Please cite only the published version using the details provided on the item record or document. In the absence of an open licence (e.g. Creative Commons), permissions for further reuse of content should be sought from the publisher or author. 
SS

29,5

436

\title{
Identifying an appropriate approach to judge low carbon buildings
}

\author{
Chinwe Isiadinso \\ School of Architecture, Design and the Built Environment, \\ Nottingham Trent University, Nottingham, UK \\ Steve Goodhew \\ School of Architecture, Design and Environment, \\ Plymouth University, Plymouth, UK \\ Julian Marsh \\ Julian Marsh \& Grochowski Architects, Nottingham, UK, and \\ Mike Hoxley \\ School of Architecture, Design and the Built Environment, \\ Nottingham Trent University, Nottingham, UK
}

\begin{abstract}
Purpose - The purpose of this paper is to report research conducted in the UK's East Midlands region which explores optimising practice for low carbon building through an architectural award system. Design/methodology/approach - To explore the complexity of the contexts, philosophies and demonstrations involved in best practice for low carbon buildings, a mixed research approach was adopted through an online survey and interviews with 13 experts.

Findings - The research provides practical means to evaluate low carbon buildings and suggests an approach where aesthetic design and technical compliance are given similar weightings. It also presents the opinions of construction professional practitioners and academics on best practice for low carbon buildings.

Research limitations/implications - The research focuses on investigating the judging criteria and opinions of construction professionals who have, in the past, strongly identified with sustainable building design practice.

Practical implications - As this research and other studies show, there is a need for a simple methodology and the use of existing tools to evaluate best practice for low carbon buildings.

Originality/value - The value of the paper lies in its purpose to establish a precedent for judging low carbon buildings through an architectural award system. Although there is a plethora of literature, tools and environmental assessment systems that point towards best practice, this research aims to highlight the underlying principles and combine these with practical methods that can enable the construction industry to achieve low carbon buildings.
\end{abstract}

Keywords United Kingdom, Building specifications, Sustainable design, Low carbon buildings, Sustainability, Construction professionals

Paper type Research paper

\section{Introduction}

It is widely accepted that the design, construction, operation and occupation of buildings have a significant impact on climate change (DETR, 1998; Sanders and Phillipson, 2003; Stern, 2007; Ürge-Vorsatz et al., 2007). Studies have also suggested

The authors wish to thank RIBA East Midlands, particularly Gwen Cottrell and the East Midlands Development Agency, particularly Peter Strutton, for funding this work and the interview respondents who gave up their valuable time to contribute to the research. 
that buildings in the UK account for approximately 50 per cent of the total carbon dioxide $\left(\mathrm{CO}_{2}\right)$ emissions (which is one of the major greenhouse gases (GHG)) (Pout et al., 2002; Department of Communities and Local Government (DCLG), 2007). Therefore, buildings are essential in the process of mitigating against climate change and depletion of natural resources. In addition, construction professionals can play a significant role in addressing design and construction issues that would reduce $\mathrm{CO}_{2}$ that result from energy demand (such as space heating, lighting, equipment/ appliances, cooling and hot water) of buildings that contribute to climate change.

The Climate Change Programme in the UK was first launched in November 2000 with one of the main strategies being the improvement of energy efficiency requirements within the building regulations. In 2006, the Climate Change Programme was published with a set of policies and priorities for action for reducing GHG particularly $\mathrm{CO}_{2}$ emissions. In 2007, the Stern Review on the Economics of Climate Change became a vital step forward in securing an effective policy action on climate change in the UK. The review considered in detail the potential cost of technologies and measures to cut emissions across different sectors. Furthermore, the Climate Change Act introduced in November 2008 puts in place a framework to achieve a mandatory 80 per cent cut in the UK's carbon emissions by 2050 (compared to 1990 levels), with an intermediate target of between 26 and 32 per cent by 2020. The expectation is that most new buildings should be carbon neutral by 2020 in the UK. This expectation is in line with the European Union Commission's 20/20 vision launched in 2010 (The Directorate-General for Climate Action (DG CLIMA), 2010). The launch further highlights the importance of construction professionals to adhere to legislative framework (such as the building regulations) in the process of designing and constructing buildings. Part L (conservation of fuel and power) of the building regulations has been updated both in 2006 and 2010 to encourage the delivery of low carbon buildings by construction professionals. The government had also set up a low carbon transition plan (DECC, 2009). This paper examines the judging criteria of designing low carbon buildings and the potential of delivery by construction professionals.

\section{What is a low carbon building?}

There is much debate as how best to define a low carbon building. The definition of a low carbon building in the technical guidance of the Code for Sustainable Homes (CSH) is at the forefront of this debate. Hence, there have been calls from the industry for a clear definition of what is "zero carbon" and a need for a universally acceptable definition. The UK government's "Low carbon transition plan" (DECC, 2009) has set targets for achieving zero carbon in all new homes from 2016 and in all new non-domestic buildings from 2019 (DCLG, 2007). However, prior to the CSH becoming mandatory by law for new buildings from April 2008, a number of approaches and concepts have been associated with defining and describing a low carbon building. Subsequently, there are two widely recognised design approaches which fit the description of low carbon buildings. They are "an autonomous house" and "PassivHaus design" approaches. Both design concepts have a number of features that establish the difference between low-impact environmental buildings and conventional buildings (see Table I). Moreover, the commonality between the two design concepts potentially demonstrates best practice for achieving and demonstrating a low carbon building. Furthermore, Williams (2010) and Sartori and Hestnes (2007) suggest that a low carbon building is a building specifically
Low carbon buildings

437 
$\mathrm{SS}$

29,5

\section{8}

Table I.

Comparison between conventional and PassivHaus design/ autonomous house
Conventional house

PassivHaus design/autonomous house

Dependent on the mains drainage system and gas supply

Not necessarily integrating renewable

resource in the early stage of design

High environmental impact

Mainly dependent on fossil fuel

Space heating almost 100 per cent dependent

on gas or electric heating systems

The energy required for space heating is typical more than $15 \mathrm{kWh} / \mathrm{m}^{2}$

Thermal bridging allowed
Independent energy service and waste disposal systems

Mandatory to integrate renewable resource in the early stage of design

Low or zero environmental impact

Potentially not dependent on fossil fuel

Space heating requirement up to 90 per cent less than conventional building

The energy required for space heating must not exceed $15 \mathrm{kWh} / \mathrm{m}^{2}$

Thermal bridging should be negligible at $<0.01 \mathrm{~W} / \mathrm{m}^{2} \mathrm{~K}$

designed and engineered with the intention to reduce $\mathrm{CO}_{2}$. This means it should emit significantly less $\mathrm{CO}_{2}$ than conventional buildings over their lifetime.

An "autonomous house" is described as a house that operates independently from any external inputs except those of its immediate environment. The house is not linked to the mains service gas, water, electricity or drainage, instead uses energy sources of the sun, wind and rain to service itself and process its own waste (Vale and Vale, 2002). A PassivHaus design concept is a house with reduced requirements for space heating and cooling with no compromise for comfort and allows potentially a small quantity of renewable technology supply (BRE, 2008). To this end, the definition of a zero carbon home is that in which the net $\mathrm{CO}_{2}$ emissions takes into account emissions associated with all energy use in the home to be equal to zero or negative across the year (DCLG, 2008; UKGBC, 2008).

The universality of domestic building provides a base case to define a low carbon building. Vale and Vale (2002) argue that occupants in a home can develop behaviour and habits which can translate into low carbon lifestyle and may ultimately lead to the development of low carbon architecture.

\section{Overview of the construction professionals and zero carbon definition}

The current ideas and practices of different construction professional bodies (such as RICS, CIOB and RTPI) add to the debate of defining and establishing the delivery of low carbon buildings in the UK. This research has focused on how an architectural award system conceived by the East Midlands RIBA can assist in establishing the delivery of low carbon buildings. Therefore, it was deemed important to review what other construction professional bodies are doing towards establishing the delivery of low carbon buildings. This was carried out through a desktop research. The desktop research indicated that across the board all construction professional bodies were responding to government policies and legislation. Specifically, professional bodies responded to the definition of zero carbon homes set by DCLG and also participated in the consultation exercise organised by DCLG to facilitate the process of defining zero carbon measures for domestic and non-domestic buildings (DCLG, 2009a, b).

Furthermore, there existed information placed on each construction professional body's web site relating to issues of sustainable development and climate change. This 
information was in the form of guidance documents and organisation of events (such as CPD programmes) and workshops to assist members with professional practice (RICS, 2009; RTPI, 2009; CIOB, 2007). It was further observed that most construction professional organisations had a "generic outlook" on what was required to design and construct low carbon buildings. For example, the common issues addressed at both micro and macro levels included efficient energy supply, decarbonising of the national grid, reducing energy demands through improved insulation measures, improving the skills gap for sustainable design and renewable technologies and managing community energy resources. These issues may be appropriately linked with the primary competency of each construction professional body's area of expertise. Through registration, examination and the articles of association and statutes defined for membership, each professional body has its area of expertise in designing and constructing buildings fit for the built environment. For example, RICS is concerned with achieving cost effective measures and risk management, $\mathrm{CIOB}$ is concerned with applying excellent construction quality and RTPI is concerned with planning. All these can then subsequently assist in addressing climate change and the delivery of best practice for low carbon buildings.

\section{Methodology of study}

The research examined the judging criteria of designing low carbon buildings and the potential of delivery by construction professionals. A quantitative and qualitative methodological approach was adopted in this research, which was an online survey and interviews. This paper focuses on the qualitative approach which consisted of the interviews with construction professionals. The interviews sought to address research questions that were based on the identified essential variables associated with low carbon buildings and sustainable buildings (Gething and Bordass, 2006). Some of these identified variables that relate to low carbon buildings include architectural design, building performance, renewable technologies, sustainability assessment methods and measurement and numerical evidence. Data were collected by means of telephone interviews with pre-prepared semi-structured questions. The semi-structured questions for the interview were divided into three sections:

(1) the technical and design-related elements of the award;

(2) ethos of the award and its design; and

(3) further comments and assistance.

All the respondents were construction professionals who had a substantial track record or linking expertise in sustainable design in both industry and academia. The number of interviewees was 13 in total. This was the number of experts that agreed to contribute to the research. The interviews lasted between one and a half hours and provided a wider picture on the practice and potential delivery of low carbon buildings in the UK. The data collected were analysed through the use of the five themes mentioned above as a series of variables that relate to low carbon buildings and a sixth theme "post occupancy evaluation". The findings of the interviews are presented in the next section of the paper.

\section{Results and discussion}

The results show the diverse nature of the construction professionals who participated in the interview process. The interviewees' opinions concerning the purpose of the
Low carbon buildings

439 
SS

29,5

440

award and other aspects of the award process with selected quotes to highlight the diversity of opinions are presented. Within the context of the research, interviewees were asked "what do you feel is the main purpose of the RIBA hosting a regional low carbon award?" Out of 13 interviewees, the response given by more than 50 per cent of the interviewees can be summarised as follows:

(1) to encourage the design and development of low carbon buildings;

(2) to encourage regional development of low carbon buildings;

(3) to create exemplar and demonstration projects that acknowledge best practice and real building performance; and

(4) for dissemination as well as promoting awareness and recognition by the public of low carbon buildings.

Since none of the interviewees conferred with each other before giving a response to the question, it may be genuinely interpreted that these are four factors that should be considered in developing a critical mass in the delivery and uptake of low carbon buildings. Other responses in the form of quotes include:

- "Focus should be on energy in-use rather than predicted".

- "Low carbon buildings are possible. However they need to be stunning and outstanding".

- "To push the low carbon design further up the agenda".

- "Oh! Not another award".

- “Government drivers such as 2019 all new buildings to be low carbon”.

Another important aspect of the interviewees responses that related to the process of the award was associated with this question - "how should the scheme evolve as we approach the year 2016 and how should the award criteria track progress in meeting future zero carbon targets". Some of the responses were as follows:

- "Need to emphasise getting better 1st stage low carbon, 2nd stage carbon neutral, 3rd stage carbon negative”.

- "Buildings should become more efficient over time, higher minimums; credit for offsite generation, code level 4 starting point”.

- "Sustainable code level 6 - but there are not a lot out there - code 5 might be a good comparison”.

- "Holistic view of what low carbon really means".

There is a recognition that this research aimed to identify the underlying principles of low carbon building design and therefore it was important to highlight the key points from the interviewees' opinions of judging criteria and delivery of low carbon buildings. The key points are presented in Table II and grouped into six categories that are associated with low carbon buildings and sustainability. The robustness of the key points indicate that the differences of opinion as stated by the interviewees are largely dependent on what the respondent perceived as a way forward to judging and delivering low carbon buildings. For example for architectural design, reference is made to innovative design and energy conservation approach, whilst for numerical evidence a simple measurement showing energy performance in $\mathrm{kWh} / \mathrm{m}^{2}$ is suggested. 


\begin{tabular}{|c|c|}
\hline Categories & Key points \\
\hline \multirow[t]{4}{*}{ Architectural design } & Innovative design approach \\
\hline & Holistic design approach \\
\hline & Flexibility and adaptability \\
\hline & Energy conservation approach \\
\hline \multirow[t]{4}{*}{ Building performance } & Demonstration of passive low carbon design \\
\hline & Demonstration of excellent construction quality \\
\hline & Robustness of the design to function from the first day of \\
\hline & occupancy \\
\hline \multirow[t]{2}{*}{ Renewable technologies } & Maximising the use of renewable technologies \\
\hline & $\begin{array}{l}\text { Adaptable integration of renewable technology into the fabric of } \\
\text { existing buildings }\end{array}$ \\
\hline \multirow{3}{*}{$\begin{array}{l}\text { Sustainability assessment } \\
\text { methods }\end{array}$} & Use simple energy-based assessment system such as Carbon Buzz \\
\hline & $\begin{array}{l}\text { Avoid complex assessment systems such as BREEAM and the } \\
\text { code }\end{array}$ \\
\hline & $\begin{array}{l}\text { Develop a tool that can establish the } \mathrm{kWh} / \mathrm{m}^{2} \text { or } \mathrm{kgCO} / 2 \mathrm{~m}^{2} \text { energy } \\
\text { usage }\end{array}$ \\
\hline \multirow{6}{*}{$\begin{array}{l}\text { Measurement with } \\
\text { numerical evidence }\end{array}$} & Actual performance which includes embodied energy use such as \\
\hline & Davis Langdon software \\
\hline & Simple measurement showing $\mathrm{kWh} / \mathrm{m}^{2}$ \\
\hline & A possible sequential test showing the balance between \\
\hline & sustainability, $\mathrm{CO}_{2}$ and architecture \\
\hline & $\begin{array}{l}\text { Levels of carbon emissions associated with the building fabric and } \\
\text { energy consumption }\end{array}$ \\
\hline \multirow[t]{3}{*}{ Post-occupancy evaluation } & Create awareness and educate building occupants \\
\hline & Engage with building occupants' lifestyle \\
\hline & $\begin{array}{l}\text { Long-term (for at least two years) monitoring and possible } \\
\text { adaptation of actions }\end{array}$ \\
\hline
\end{tabular}

Low carbon buildings

441

Key points for the delivery of low carbon buildings

On the other hand, the key points listed in Table II can also be regarded as one of the approaches to deliver low carbon buildings and therefore a step forward in setting up a judging criteria for building projects that encapsulate the essence of low carbon buildings. This supports the general characteristics for basic judgement criteria that may apply to an architectural competition award system (Kazemian and Rönn, 2009). The responses given by the interviewees may also be read in the context of their significance to an architectural award system, which is to promote the design of low carbon buildings and how it can meet the UK's target of zero carbon emissions from buildings by 2050 .

Nevertheless, there is urgent demand from the general public and construction professional practitioners for evidence associated with actual reduction of carbon emissions from buildings. The evidence-based design that requires measurement of low carbon buildings can be described as "evaluating building performance". For example, energy performance of the building is measured in $\mathrm{kWh} / \mathrm{m}^{2}$. In this research, the interviewees were asked "what is the balance in marks between the numerical evidence versus architectural design?". The interviewees gave their response mostly in the form of percentage scores. The responses reflect a diverse opinion of where the marks should be in terms of numerical evidence vs architectural design. Their responses include - "2/3 low carbon vs $1 / 3$ architecture"; "30 per cent architecture vs 70 per cent performance"; "90 per cent performance - good overall vs 
$\mathrm{SS}$

29,5

442
10 per cent architecture"; "75 per cent measured vs 25 per cent architecture"; and "60 per cent performance vs 40 per cent design".

Table III shows a synthesis of the wider picture of interviewees' opinion towards the delivery of low carbon buildings. Table III is also categorised into six themes as Table II. The interviewees identified notable levels of performance judging criteria for low carbon buildings (see Table III). Specifically, interviewees suggested that innovation and pioneering methods combined with renewable technologies might assist in the delivery of low carbon buildings. Their responses supports a previous study on the judging criteria and sustainability checklist that might be used in assessing levels of building performance for sustainable buildings (Gething and Bordass, 2006).

One can deduce from the responses in Table III that several factors have the potential to influence best practice for low carbon buildings. Some of these factors as
Categories Quotes from interviewees

Architectural design

Building performance

Renewable technologies no 'green bling"' architecture" regard for architecture"
Table III.

Selected quotes relevant to the delivery of low carbon buildings
"Architecture first performance second [...] then the tie breaker is the Architect and then 'all round' - some things are 'bigger' then performance

"Good piece of architecture 50\% Carbon element 50\% very difficult" "Building not being discussed because people don't like it. Not poor

"Replicability very important and can be rolled out." "Some 'green' people view all performance and no 'architecture' - so we need a fairly high

"100\% performance! (but this is impossible)"

"Do not hide the performance behind renewable energy systems"

"Do not compare predicted with actual data, measurable bits of carbon + energy certificate - improvement over benchmark"

"Try to get predictions as close as actual"

"Energy per $\mathrm{m}^{2}$ or per building? performance? prefer total carbon"

"World is full of buildings that perform to $50 \%$ over the predicted"

"Need predicted first - not proven but it is a start"

"Less about BREEAM - more about 'actual performance"

"Some mechanism to take into account the energy due to differences

between behaviour and appliances and the 'bits' need to be identified

which the architect is responsible for"

"Best innovations are the mix between people and technology [...]

Lifestyle change drivers"

"From the use of renewable - carbon negative by 2017 but perhaps not as this is very site specific not everyone can be pioneers"

"Renewable - need to put to the test"

"Aware of limitations of renewables not social engineering, devil is in the detail"

"Survey for wind calculations, renewables - no. off site renewables?"

"More relaxed, e.g. eco-trinity but not green tariffs CHP - where does this fit?"

"Innovation - rehashes or previous designs. Innovation is very important" "Doesn't need to be innovative. Working is good. Basics have been known for the last 30 years" 
Categories

Sustainability assessment methods

Measurement with
numerical evidence

Measurement with
numerical evidence

Post-occupancy evaluation
Quotes from interviewees

"Compare bench mark as compared $\mathrm{kW} / \mathrm{m}^{2}$ usage"

"Separate energy and carbon"

"Energy efficient equipment in the building itself, e.g. PCs [...] Quality of detailing [...] example - pressure test results [...] Insulation + air tightness reflect detailing standards $[\ldots] 80 \%$ approx correct $[\ldots]$ focus on the basics - much is out of our control [...] passive components needs [...] site manager"

"Energy first then carbon second [...] manager/clients/designers main focus is energy"

"Efficient off-site generation is OK VALUE from generation autonomy of supply should not be the only direction, selling on the 'green' generation" "Carbon emissions are the 'problem' less about BREEAM - more about 'actual' performance"

"Using building regulations for other policy [...] Low carbon policy document suggested hierarchy - (1) Lower loads; (2) Carbon compliance (PV, Biomass); and (3) Compensating measure of actions (stuff you do elsewhere)"

"Descriptive stuff - leave the numbers alone except for energy use" " $\mathrm{kWh} / \mathrm{m}^{2}$ better more long lived measure and less easy to attack" "kW/person based upon average occupancy." "PassivHaus uses kW/m² annual load [...] peak load like how much does it cost to heat the building in extreme weather?"

"Exemplar and beyond best practice - double thermal, i.e. $\frac{1}{2}$ 'u' values $\frac{1}{2}$ airtightness or $30 \%$ of building regulations"

"Projected emissions all is architecture $\mathrm{CO}_{2}$ should be part of this all" "20 $\mathrm{kg} / \mathrm{m}^{2}$ but much easier to get to $25 \mathrm{~kg} / \mathrm{m}^{2}$ but more people could use this"

"An absolute tool that measures $\mathrm{kWh} / \mathrm{m}^{2}$ or $\mathrm{kgCO}_{2} / \mathrm{m}^{2}$ "

"Not just a box ticking exercise involve the users in the development work"

"At least 2 years for a building beyond 6 months snagging 3-4 years preferable"

"Measure in use 3 years since completion award for building being occupied POE data - reliable data - no 'claims' put award into the sphere of occupation in plans"

"Feedback from occupants - 'comfortable' - a 'good' building perhaps refers to the solitude of buildings but occupiers don't understand the process"

"Linkage between buildings and their use/occupant"

"Design team need to understand "how' the buildings are occupied" "Occupied buildings over a period (1 year), compliance evidence all figures must be verified and signed off by an environmental engineer, fitness to be built"

"A very good idea and reflections on the back of POE"

"No POE encouraging an element of reality low key conception and environmental design"

Low carbon buildings

443

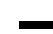

443

Table III.

identified by the interviewees include replicability of architectural building design, energy performance approach, lifestyle change drivers, low carbon policy and feedback from occupants. However, these factors may be, most likely influenced by changes driven by government legislation (such as the update to the part $\mathrm{L}$ of the 
SS

29,5

444 building regulations in 2010 and energy performance certificates) and incentives as well as demand from environmentally conscious building occupants/consumers (such as awareness of the A to $G$ ratings of energy performance certificates). There are similarities found in the responses given by the various respondents in Table III that relate to the "balance of marks" between the performance and architecture for judging and delivering low carbon buildings. For example, some interviewees stated that - "a good piece of architecture should be $50 \%$ and the Carbon element 50\%!"; "this is very difficult"; " $50-50 \%$ actual performance"; " $50 \% / 50 \%$ both important but in equal proportion"; and "it should be 50-50 neither should dominate, poor elements in each made up for in other elements". These responses indicate that varied levels of performance and holistic judging criteria with architectural design, if balanced within a mechanism should be the way forward to judge low carbon buildings. However, the challenge lies with validating the delivery system and methodology that balances both architectural design and performance in equal proportion to produce low carbon buildings.

Furthermore, other responses from interviewees also indicate that creating an architectural award system to demonstrate and establish low carbon buildings will require a diverse and complex approach. This may lead to a rationale for ensuring that as well as adopting a specific approach for evaluating low carbon buildings, it is important to evaluate the buildings through a holistic format such as the six themes listed in Tables II and III. However, by verifying or validating the approach, a mechanism can be developed and classified accordingly, and then form part of the essential characteristics to assist in the delivery of low carbon buildings. For example, responses such as "good design and technically working buildings"; "cannot be low carbon without proving it over time"; "how much $\mathrm{CO}_{2}$ does your building make? Important but other elements also are important"; and "compliance approach + transport + siting of a building"; all these statements indicate that validation of all aspects of the building design and process are necessary in judging a low carbon building. Lastly another important aspect raised by the interviewees is achieving economies of scale as a crucial aspect in the development and uptake of low carbon buildings with the provision of evaluation programmes better known as "environmental assessment methods" (such as BREEAM, CSH). Responses from interviewees that support this idea include: "energy efficient equipment in the building itself e.g. PCs [...] Quality of detailing [...] example - pressure test results $[\ldots]$ Insulation + air tightness reflect detailing standards [...] 80\% approx correct $[\ldots]$ focus on the basics - much is out of our control [...] passive components needs [...] site manager". "kW/person based upon average occupancy". "PassivHaus uses $\mathrm{kW} / \mathrm{m}^{2}$ - annual load [...] peak load like how much does it cost to heat the building in extreme weather?" and "life cycle cost and the environmental impact of the building".

\section{Summary and conclusion}

There is an inherent complexity in defining low carbon buildings. However, an integrated approach to low carbon building solutions in the construction industry should involve all construction professionals and stakeholders in the industry. Conversely, there is a recognition that many practitioners (such as architects and building services engineers) in the construction industry choose to intuitively prescribe unique solutions from their own perceptions and experience of established professional practice and organisational history. These unique ideas and solutions can lead to questions (such as what kind of parameters best suits the design of low carbon 
buildings and would construction professionals consider designing a low carbon building without government legislation and incentives?).

The findings from the research have shown that for judging criteria and delivery of low carbon buildings, there are diverse ways to approach and implement. However, evaluating a low carbon building could be simplified by combining all the highlighted issues (such as economies of scale, levels of assessment and balance between architecture and performance) and factors (such as replicability of design, feedback from building occupants, energy performance approach) to form a clear mechanism for judging and delivering low carbon buildings.

On the other hand, each of the construction professional organisations have responded on behalf of their members concerning the issues relating to zero carbon buildings as discussed in section 3 . These responses with the characteristics identified by the interviewees can form part of the "big picture" and relate to the construction industry's active participation in delivering low carbon buildings and taking appropriate action to enable a low carbon economy in the UK. Thus, the goal to meet the 80 per cent reduction of carbon emissions by 2050 in the UK may be seen as possible and not just an aspiration for the construction industry. Overall, this may further assist in the development of an appropriate framework for evaluating low carbon buildings, which can inform building design in the future.

\section{References}

BRE (2008), PassivHaus Primer, BRE, PassivHaus, available at: www.passivhaus.org.uk/ filelibrary/BRE-PassivHaus-Primer.pdf

CIOB (2007), The Green Perspective - A UK Construction Industry Report on Sustainability, CIOB, Ascot, available at: www.ciob.org.uk/sites/ciob.org.uk/files/WEB-INF/files/ documents/TheGreenPerspective.pdf

Department of Communities and Local Government (DCLG) (2007), Building a Greener Future: Policy Statement, DCLG, London, available at: www.communities.gov.uk/publications/ planningandbuilding/building-a-greener

DCLG (2008), Definition of Zero Carbon Homes and Non-Domestic Buildings: Consultation, DCLG, London, available at: www.communities.gov.uk/publications/planningandbuilding/ zerocarbondefinition

DCLG (2009a), Zero Carbon for New Non-Domestic Buildings - Consultation on Policy Options, DCLG, London, available at: www.communities.gov.uk/documents/planningandbuilding/ pdf/1391110.pdf

DCLG (2009b), Proposed Changes to Part L and Part F of the Building Regulations: Consultation Paper, DCLG, London, available at: www.communities.gov.uk/publications/ planningandbuilding/partlf2010consultation

DECC (2009), The UK Low Carbon Transition Plan. National Strategy for Climate and Energy, DECC, Guildford, available at: www.officialdocuments.gov.uk/document/other/ 9780108508394/9780108508394.pdf

DETR (1998), Rethinking Construction, Construction Task Force, DETR, London.

The Directorate-General for Climate Action (DG CLIMA) (2010), DG CLIMA, available at: http:// ec.europa.eu/dgs/clima/mission/index_en.htm

Gething, B. and Bordass, B. (2006), "Rapid assessment checklist for sustainable buildings", Building Research \& Information, Vol. 34 No. 4, pp. 416-26.

Kazemian, R. and Rönn, M. (2009), "Finnish architectural competitions: structure, criteria and judgement process", Building Research \& Information, Vol. 37 No. 2, pp. 176-86. 
SS

29,5

446
Pout, C.H., MacKenzie, F. and Bettle, R. (2002), "Carbon dioxide emissions from non-domestic buildings: 2000 and beyond”, BRE report 442, Building Research Establishment, Watford.

RICS (2009), RICS Global Carbon Capacity Index - ZC2, RICS London, available at: www.rics.org/ site/scripts/download_info.aspx?fileID $=6883$

RTPI (2009), "Low carbon innovation and delivery - a report commissioned by the National Endowment of Science, Technology and Arts (NESTA)", Tyndall Centre for Climate Change Research, Norwich, London, 18 August, available at: www.rtpi.org.uk/item/2895/ (accessed March 2010).

Sanders, C.H. and Phillipson, M.C. (2003), "UK adaptation strategy and the technical measures: the impacts of climate change on buildings", Building Research \& Information, Vol. 31 Nos 3-4, pp. 210-21.

Sartori, I. and Hestnes, A.G. (2007), "Energy use in the life cycle of conventional and low-energy buildings: a review article", Energy and Buildings, Vol. 39 No. 3, pp. 249-57.

Stern, N. (2007), The Economics of Climate Change. The Stern Review, Cabinet Office - HM Treasury, Cambridge University Press, Cambridge.

UKGBC (2008), “The definition of zero carbon”, Zero Carbon Task Group report, UKGBC, available at: www.ukgbc.org/site/document/download/?document_id $=180$ - Similar (accessed April 2010).

Ürge-Vorsatz, D., Danny Harvey, L.D., Mirasgedis, S. and Levine, M.D. (2007), "Mitigating $\mathrm{CO}_{2}$ emissions from energy use in the world's buildings", Building Research \& Information, Vol. 35 No. 4, pp. 379-98.

Vale, B. and Vale, R. (2002), The New Autonomous House - Design and Planning for Sustainability, Thames and Hudson, London.

Williams, C. (2010), Biodiversity for Low and Zero Carbon Buildings: A Technical Guide for New Build, RIBA Publishing, London.

\section{Corresponding author}

Chinwe Isiadinso can be contacted at: Chinwe.isiadinso@ntu.ac.uk

To purchase reprints of this article please e-mail: reprints@emeraldinsight.com Or visit our web site for further details: www.emeraldinsight.com/reprints 